\title{
Cercosporiose progression in the agroforestry consortium coffee-rubber trees
}

\section{Progresso da cercosporiose em consórcio agroflorestal café-seringueira}

\author{
Humberto Godoy Androcioli ${ }^{1 *}$; Heverly Morais ${ }^{1}$; \\ Ayres de Oliveira Menezes Júnior²; Adriano Thibes Hoshino ${ }^{3}$; \\ Leonardo Godoy Androcioli ${ }^{4}$; Paulo Henrique Caramori ${ }^{5}$
}

\begin{abstract}
Cercospora coffeicola is one of the primary diseases that affect coffee plants. Studies indicate that shaded coffee plants reduce the incidence of this disease and that the management of trees and coffee plants arrangement influence in the dissemination of cercospora. The objective of this study was to evaluate the incidence and severity of $C$. coffeicola at different distances from double rows of rubber trees (Hevea brasiliensis muell. arg.) at two different sunlight exposures (north and south). This study was conducted in Londrina, Parana, between 2008 and 2010, with adult plants of the IAPAR 59 cultivar (Coffea arabica L.) grown at a spacing of $2.5 \mathrm{~m} \times 1.0 \mathrm{~m}$. The distances between the double rows of rubber trees were 13,16 and $22 \mathrm{~m}$, compared to plants grown under full sun. The disease incidence was assessed monthly by using a non-destructive method. This analysis was conducted on coffee leaves from the third and fourth pairs of two plagiotropic branches, on eight plants per plot, with five replications. These data were used to calculate the area under the curve for the incidence of the brown eye spot. The highest disease incidence occurred in the coffee plants grown under full sun, whereas lowest disease occurred on plants located at up to two meters away from double rows of rubber trees. The incidence of Cercospora leaf spot increased with the distance from the double rows of rubber trees. The results demonstrate that the mapping of cercospora incidence in shaded coffee plants is essential to determinate the best spacing and plants arrangement.
\end{abstract}

Key words: Coffea arabica, Cercospora coffeicola, Hevea brasiliensis, coffee shading

\section{Resumo}

A Cercospora coffeicola é uma das principais doenças que afetam o cafeeiro. Estudos apontam que o cultivo de café arborizado reduz a incidência dessa doença, sendo que o manejo e a disposição das árvores e dos cafeeiros influenciam na disseminação da cercosporiose. O objetivo deste trabalho foi avaliar a incidência da $C$. coffeicola em diferentes distâncias de cafeeiros em relação a filas duplas de seringueira (Hevea brasiliensis Müell. Arg.), nas faces norte e sul de exposição solar. O estudo foi realizado em Londrina, PR, no período de 2008 a 2010, em cafeeiros adultos do cultivar IAPAR 59

1 Eng ${ }^{\text {os }}$ Agros , Drs. em Agronomia, Instituto Agronômico do Paraná, IAPAR, Londrina, PR, Brasil. E-mail: handrocioli@iapar.br; heverly@iapar.br

2 Eng $^{\mathrm{o}}$ Agr $^{\mathrm{o}}$, Prof. Dr. em Biociência/Zoologia, Dept ${ }^{\mathrm{o}}$ de Agronomia, Universidade Estadual de Londrina, UEL, Londrina, PR, Brasil. E-mail: ayres@uel.br

3 Eng ${ }^{\circ}$ Agr $^{\circ}$, Discente do Curso de Doutorado em Agronomia, UEL, Londrina, PR, Brasil. E-mail: hoshinoagro@gmail.com

4 Eng $^{\circ}$ Agr $^{\circ}$, Discente do Curso de Doutorado em Agronomia/Agricultura, Universidade Estadual Paulista, UNESP, Botucatu, SP, Brasil. E-mail: leonardoandrocioli@gmail.com

5 Eng ${ }^{\circ}$ Agr ${ }^{\circ}$, PhD em Agrometeorologia, IAPAR, Londrina, PR, Brasil. E-mail: caramori@iapar.br

* Author for correspondence 
(Coffea arabica L). As distâncias entre seringueira em filas duplas foram de 13, 16 e 22 m, comparadas com plantio a pleno sol. A avaliação da incidência da doença foi realizada por método não destrutivo, por meio da contagem de folhas doentes nas folhas do terceiro e quarto pares de dois ramos plagiotrópicos dos cafeeiros. Com base nesses dados calculou-se a área abaixo da curva de progresso da incidência da cercosporiose. A maior incidência da doença ocorreu nos cafeeiros cultivados a pleno sol. Os cafeeiros cultivados até dois metros distantes das seringueiras em filas duplas apresentaram menor incidência da doença. A incidência de cercosporiose do cafeeiro aumentou com o incremento da distância das plantas em relação às seringueiras em filas duplas. Os resultados demonstram que o mapeamento da incidência da cercospora em cafeeiros arborizados é fundamental para a determinação dos melhores espaçamentos e disposição das plantas.

Palavras-chave: Coffea arabica, Cercospora coffeicola, Hevea brasiliensis, sombreamento de cafeeiro

\section{Introduction}

Agroforestry systems of coffee (Coffea arabica L.) and rubber (Hevea brasiliensis Müell. Arg.) are alternatives for diversifying agricultural production. These systems could contribute to the economic stability of farmers and meet the natural rubber deficit in Brazil.

Agroforestry systems improve the microclimate of coffee plantations by reducing leaf temperatures, increasing relative humidity, providing frost protection and reducing the adverse impacts of wind and rain (CARAMORI et al., 2004; MORAIS et al., 2007; PEZZOPANE et al., 2007). Planting trees increases soil organic matter inputs from leaf fall, conserves moisture, increases the water absorption and infiltration capacity and reduces nitrogen losses (BLACK; ONG, 2000; JARAMILLO; CHÁVES, 1999; HAIRIAH et al., 2006). Coffee trees in agroforestry systems reduce the emergence of invasive plants (ROMERO-ALVARADO et al., 2002), decrease the coffee leaf miner (Leucoptera coffeella) population (GUHARAY et al., 2001; LOPES et al., 2012) and decrease the incidence of cercospora leaf spot (Cercospora coffeicola) (SALGADO et al., 2007).

Cercospora leaf spot is one of the major diseases that affect coffee trees and occurs in nearly all coffee plantations in Brazil, with potential to cause coffee production losses of up to $30 \%$ (ZAMBOLIM et al., 1997). These losses result from the formation of leaf spots, which reduce photosynthetic leaf area and promote early leaf fall (MARTINS et al.,
2004; SAMAYOA; SANCHEZ, 2000). In addition, C. coffeicola causes early ripening, wilting and premature fruit drop (GODOY et al., 1997).

Nutritional factors and low water levels in the soil can be used to predict the occurrence of cercospora leaf spot or brown eye leaf spot (BOTELHO et al., 2011; GARCIA JÚNIOR et al., 2003; SANTOS et al., 2008).

According to Salgado et al. (2007), the incidence of the brown eye spot from C. coffeicola is greater in coffee trees that are grown in full sun than in coffee trees that are grown in shade. In addition, Cercospora leaf spot is often greatest on the sides of coffee trees that receive the greatest light intensity (CUSTÓDIO et al., 2010).

This study evaluates the incidence of cercospora leaf spot in coffee trees grown in consortium with different rubber tree populations. The focus is on microclimate conditions modified by distances between coffee and rubber trees, exposure of coffee trees to sunlight and levels of coffee shading.

\section{Materials and methods}

The study was conducted at the Experimental Station of the Agronomic Institute of Paraná (Instituto Agronômico do Paraná - IAPAR) in Londrina, Paraná State, Brazil (2321'38.22"S and $51^{\circ} 10^{\prime} 04.15^{\prime} \mathrm{W}$, altitude $581 \mathrm{~m}$ ). The soil at this site is a clayey Rhodic Hapludox (Oxisol) (EMBRAPA, 1999). The mean annual precipitation is $1,600 \mathrm{~mm}$, and the mean annual temperature is $21^{\circ} \mathrm{C}$ (IAPAR, 
2010). In addition, average monthly climatic data were obtained from a weather station located $100 \mathrm{~m}$ from the experimental site.

Seedlings of coffee (IAPAR 59 cultivar) were planted during the first semester in 2000 at a row spacing of $2.5 \times 1.0 \mathrm{~m}$, with two plants per hole in a north-south orientation. Rubber trees (Clone PB235) were planted in the first semester of 1999. The rubber trees were oriented east to west and planted in double rows spaced $4.0 \times 2.5 \mathrm{~m}$ between plants, and in three different spacings between double rows: 13 , 16 and $22 \mathrm{~m}$. These double rows were transverse to the coffee plantation. The experiment was arranged in a randomized block design with four treatments and five replications. The coffee trees under full sun were compared with coffee trees intercropped with three different rubber tree populations representing three different shading situations.
In each type of system (rubber tree + coffee), eight coffee plants were marked at five sampling points (Figure 1). The first of these points was between the rows of rubber trees (BR), and the second point was two meters to the north side of the rubber trees. The third point was in the center of the space between the rubber tree rows (and to the north), the fourth point was in the first two meters to the south and the fifth point was in the center of the space between the rubber tree rows to the south. In the coffee monocrop $(\mathrm{Cm})$, sampling occurred at the center of the plot. Based on the three intercropping densities (13, 16 and $22 \mathrm{~m}$ between double rows of rubber trees) and the coffee monocrop, the coffee trees were marked at 16 sampling points. These points were used to understand and explore the results, which were considered as 16 treatments with five replications (Table 1).

Table 1. Description of the treatments in the agroforestry system of coffee and rubber tree. Londrina-PR, Brazil, 2010.

\begin{tabular}{lccc}
\hline Treatment & $\begin{array}{c}\text { Distance between double } \\
\text { rows of rubber trees }(\mathrm{m})\end{array}$ & $\begin{array}{c}\text { Position of the coffee plants } \\
\text { relative to the rubber trees }\end{array}$ & $\begin{array}{c}\text { Distance between double row of } \\
\text { rubber trees and coffee plants }(\mathrm{m})\end{array}$ \\
\hline $1-13 \mathrm{~S} 2$ & 13 & South & 6 and 7 \\
$2-13 \mathrm{~S} 1$ & 13 & South & 1 and 2 \\
$3-13 \mathrm{BR}$ & 16 & Between trees & 0 \\
$4-13 \mathrm{~N} 1$ & 13 & North & 1 and 2 \\
$5-13 \mathrm{~N} 2$ & 13 & North & 6 and 7 \\
$6-16 \mathrm{~S} 2$ & 16 & South & 8 and 9 \\
$7-16 \mathrm{~S} 1$ & 16 & South & 1 and 2 \\
$8-16 \mathrm{BR}$ & 16 & Between trees & 0 \\
$9-16 \mathrm{~N} 1$ & 16 & North & 1 and 2 \\
$10-16 \mathrm{~N} 2$ & 16 & North & 8 and 9 \\
$11-22 \mathrm{~S} 2$ & 22 & South & 11 and 12 \\
$12-22 \mathrm{~S} 1$ & 22 & South & 1 and 2 \\
$13-22 \mathrm{BR}$ & 22 & Between trees & 0 \\
$14-22 \mathrm{~N} 1$ & 22 & North & 1 and 2 \\
$15-22 \mathrm{~N} 2$ & 22 & North & 11 and 12 \\
$16-\mathrm{Cm}$ & - & - & - \\
\hline
\end{tabular}


The incidence of the brown eye spot in the coffee trees was non-destructively evaluated from January 2008 to December 2010 each 30 days. The number of damaged leaves on two branches from the middle-upper region of the plant was counted on the third and fourth pairs of leaves for eight plants per treatment (totaling 64 leaves on each evaluation date). Based on the obtained data, the area under the disease progress curve (AUDPC) was determined for the cercospora leaf spot incidence (AUCLSPC) using the AACPD software (CANTERI et al., 2004). A comparison between the means of the different treatments relative to the AUCLSPC was performed by using the Scott-Knott test $(\mathrm{p}<0,05$ of probability) with untransformed data and in the SASM-Agri software (CANTERI et al., 2001).

Figure 1. Schematic diagram of the experiment showing the orientation of the blocks and the distributions of the plots. A, B and C indicate the coffee plants intercropped with rubber trees in double rows spaced 13, 16 and $22 \mathrm{~m}$, respectively. Letter E represents coffee monocrop $(\mathrm{Cm})$. The numbers 13, 16 and 22 represent the distances $(\mathrm{m})$ between the double rows of rubber trees. BR, $\mathrm{S}$ and $\mathrm{N}$ represent the coffee plants within double rows, to the south and to the north, respectively. Numbers 1 and 2 represent the coffee plants at $2 \mathrm{~m}$ and at half the distances between the double rows. The open stars indicate coffee plants not evaluated, the filled stars indicate coffee plants assessed in the treatments and the quartered circles represent the rubber trees. Londrina-PR, Brazil, 2010.

A

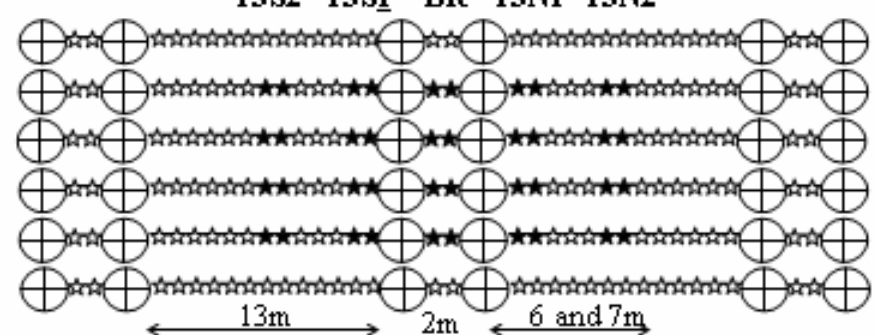

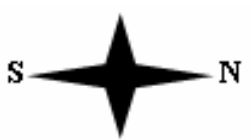

B

$16 \mathrm{~S} 2 \quad 16 \mathrm{~S} 1 \quad \mathrm{BR} \quad 16 \mathrm{Nl}$ 16N2

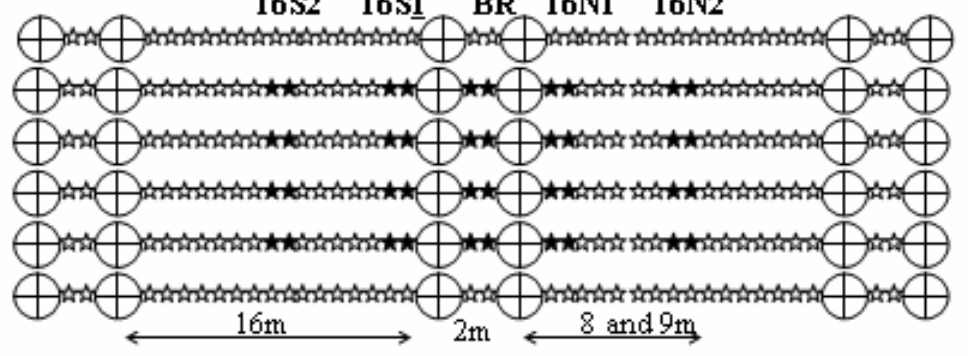

C

22S2

22S1

BR 22N1

$22 \mathrm{~N} 2$

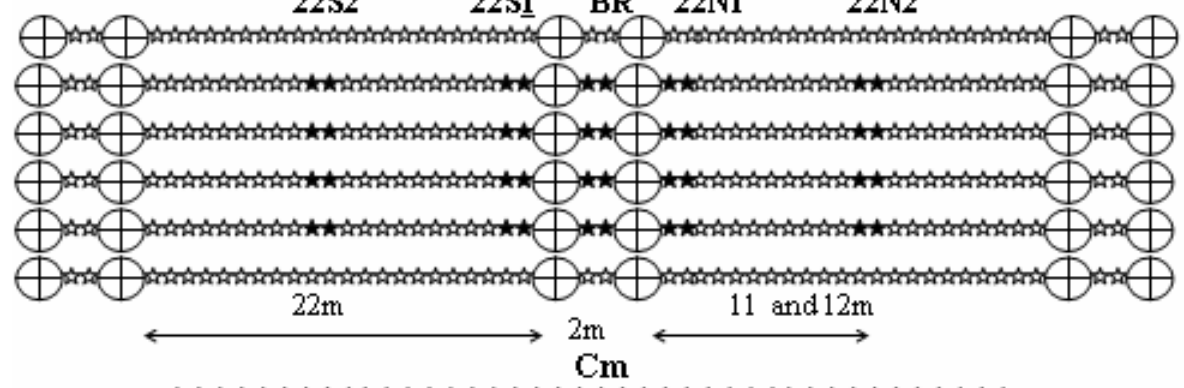

D

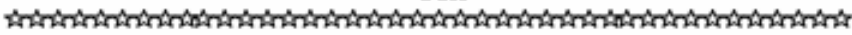

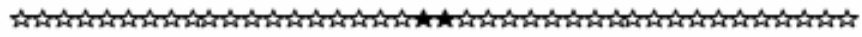

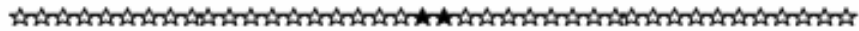

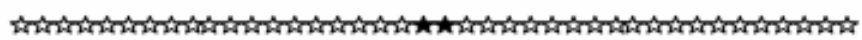

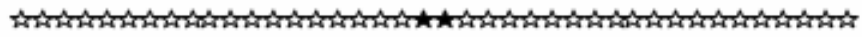

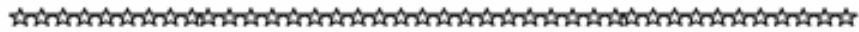
$40 \mathrm{~m}$ 20 and $21 \mathrm{~m}$ 


\section{Results and Discussion}

A significant difference in the area under the progression curve of cercospora leaf spot (AUCLSPC) was observed for the coffee trees intercropped with the rubber trees compared with those grown under full sun, for the three consecutive years evaluated. The AUCLSPC increased with the position of coffee trees relative to the positions of the rubber trees in double rows (Figure 2).

Figure 2. The area under the incidence progression curve of C. coffeicola (AUCLSPC) in the treatments for 2008 (A), 2009 (B) and 2010 (C). Treatments are described in Table 1 and Figure 1. The columns with the same letters do not differ based on the Scott-Knott test at a probability of 95\%. Londrina-PR, Brazil.
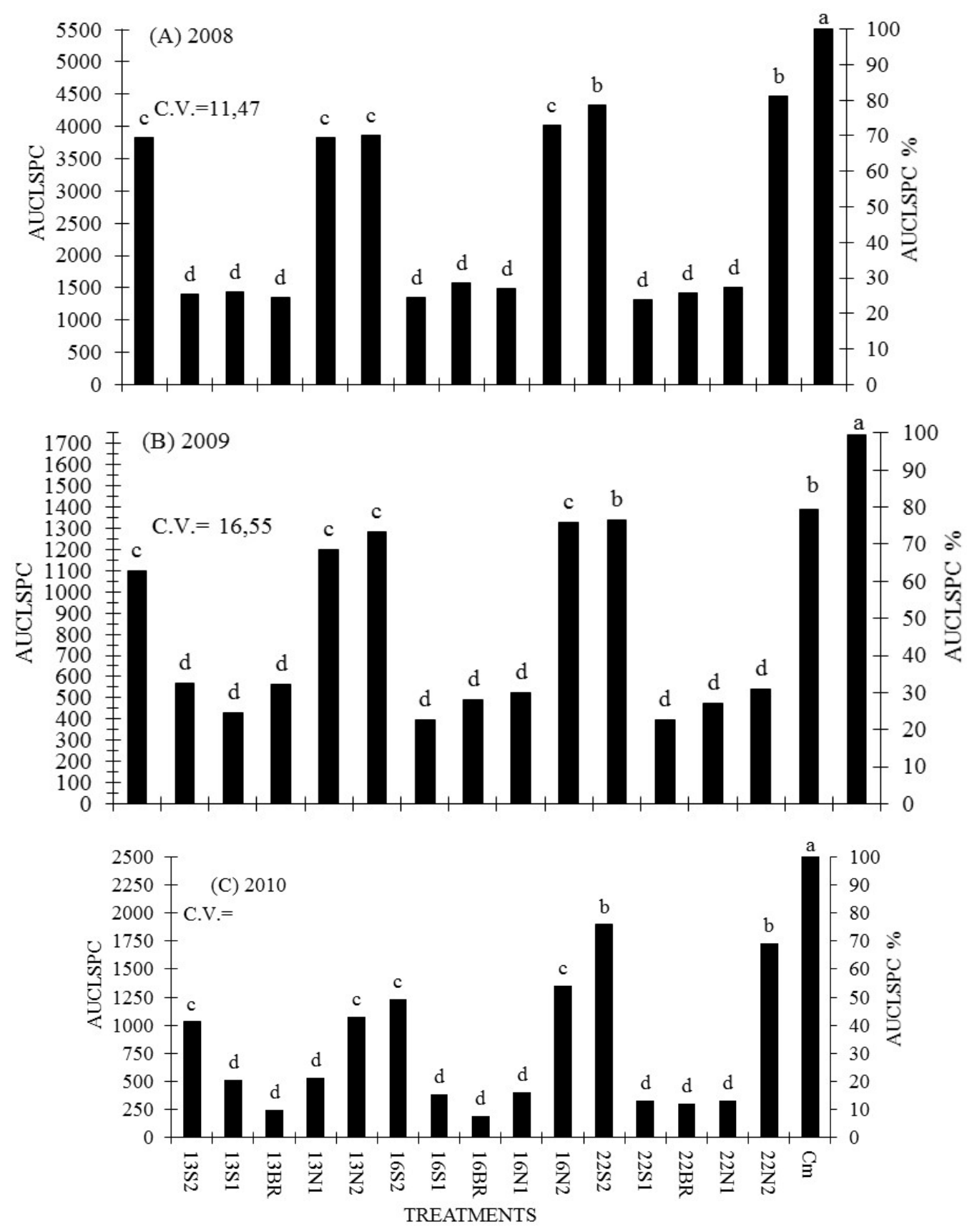
The lowest AUCLSPC values occurred in the coffee trees near the rubber trees (under the rubber trees and within $2.0 \mathrm{~m}$ away). The AUCLSPC values were $70 \%$ to $80 \%$ lower in the coffee trees near the rubber trees than in the coffee trees that were under full sun, in the years 2008 to 2010. This result occurred because the rubber trees provided shade for the coffee trees. In coffee trees that were positioned $11.0 \mathrm{~m}$ from double rows of rubber trees, the AUCLSPC was $20 \%$ to $26 \%$ lower than in the coffee trees grown under full sun. This is consistent with the results of Salgado et al. (2007) for coffee trees intercropped with different tree species. The highest disease incidence in the coffee trees grown under full sun potentially resulted from an increase in the cercosporin toxin. According to Batchvarova et al. (1992) and Daub et al. (2005), the activity and production of the cercosporin toxin by the Cercospora species increases with increasing light intensity. Daub et al. (2005) hypothesized that cercosporin kills the host cell, which allows the pathogen to access nutrients. This toxin can be a factor of aggressiveness of C. coffeicola.

Regarding exposure on the north and south sides of the coffee plants intercropped with the rubber trees, the progression of cercospora leaf spot was not significantly different from the progression in the other treatments (Figure 2). This potentially resulted from the shading of the plots by the rubber trees during the day.
The progression curve of $C$. coffeicola varied over the three years of assessment. These progression curves indicate that the greatest disease incidence occurred in 2008 and the lowest in 2009 (Figure $3)$. In the years with higher production (2008 and 2010), the coffee plants grown under full sun had higher disease incidence between February and July (peaks in May or June). Growth and maturation of the fruits occurred during this period, which required greater energy expenditure by the plant. According to Botelho et al. (2011), Garcia Júnior et al. (2003), Santos et al. (2008) and Talamini et al. (2001), this environment with little shading and nutritional imbalances (particularly with respect to nitrogen and potassium) directly affects the intensity of cercospora leaf spot attacks.

The periods with the highest cercospora leaf spot incidence (May to June of 2008 and 2010) corresponded with the periods of lowest rainfall and temperature (lower than $25{ }^{\circ} \mathrm{C}$ ) (Figures 4 and 5). The climatic conditions of high relative humidity and temperature (between 10 and $25^{\circ} \mathrm{C}$ ) are favorable to $C$. coffeicola (ZAMBOLIM et al., 1997). In addition, periods of prolonged drought and plant water deficit favor its attack (TALAMINI et al., 2001). The availability of water may have been greater in the coffee trees grown under shade during the period of low rainfall (from May to July of 2008 and 2010). According to Neves et al. (2007), water savings occur for coffee plants in agroforestry systems. In addition, the transpiration of coffee is significantly reduced grown in agroforestry systems (MORAIS et al., 2007). 
Figure 3. Epidemiological curve for the incidence progression of cercospora leaf spot, at different positions of the coffee plants relative to the double rows of rubber trees and grown under full sun in 2008 (A), 2009 (B) and 2010 (C). Treatments 13, 16 and 22, which are near the double rows of rubber trees $(\mathrm{BR} / \mathrm{S} 1 / \mathrm{N} 1)$, were grouped into mean values to improve understanding. The treatments of North (N2) and South (2) and the middle distances of 13, 16 and 22 were also grouped for each respective distance. Londrina-PR, Brazil.
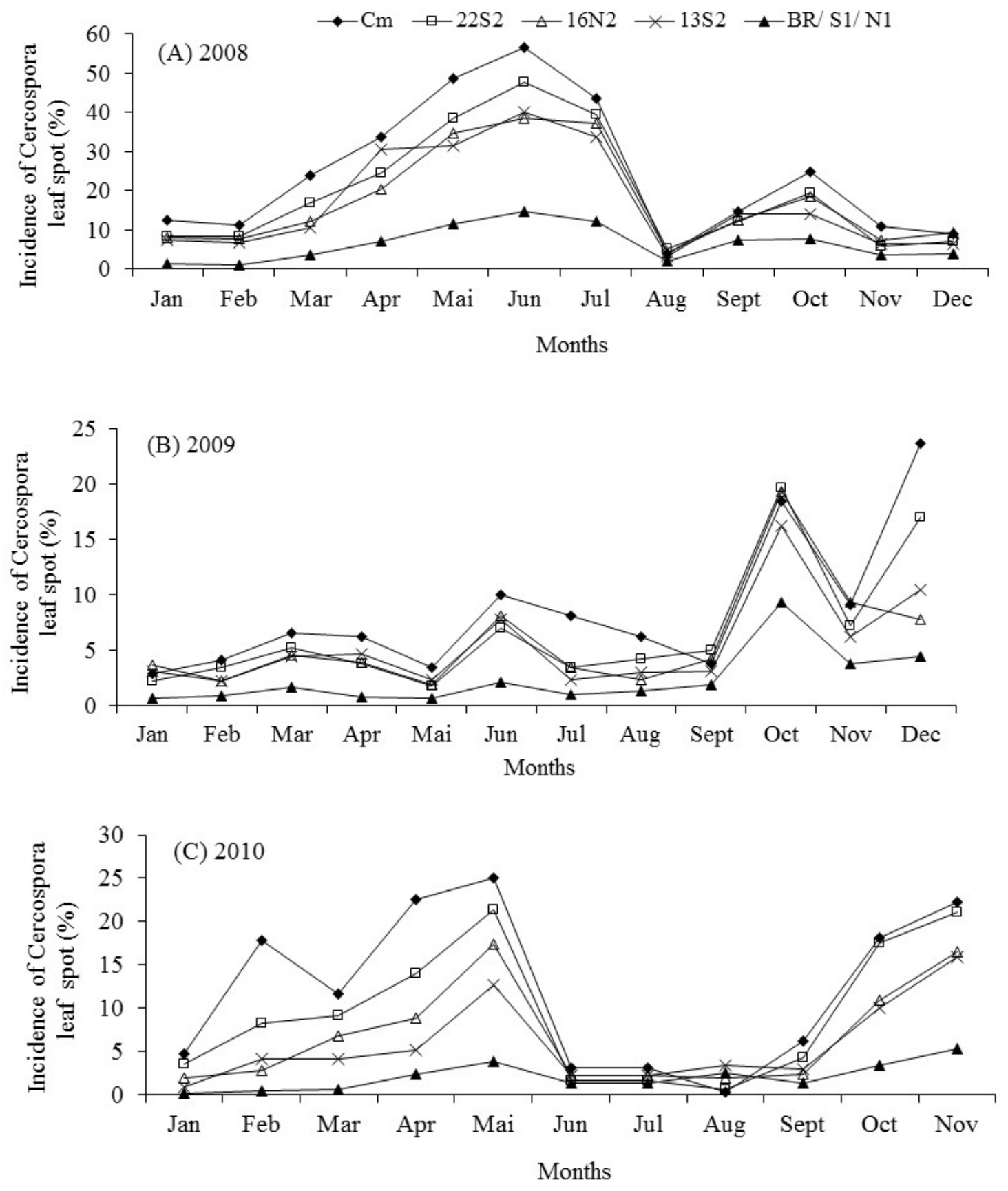
Figure 4. Monthly temperature, relative humidity and precipitation from January to December in 2008. Londrina PR, Brazil.

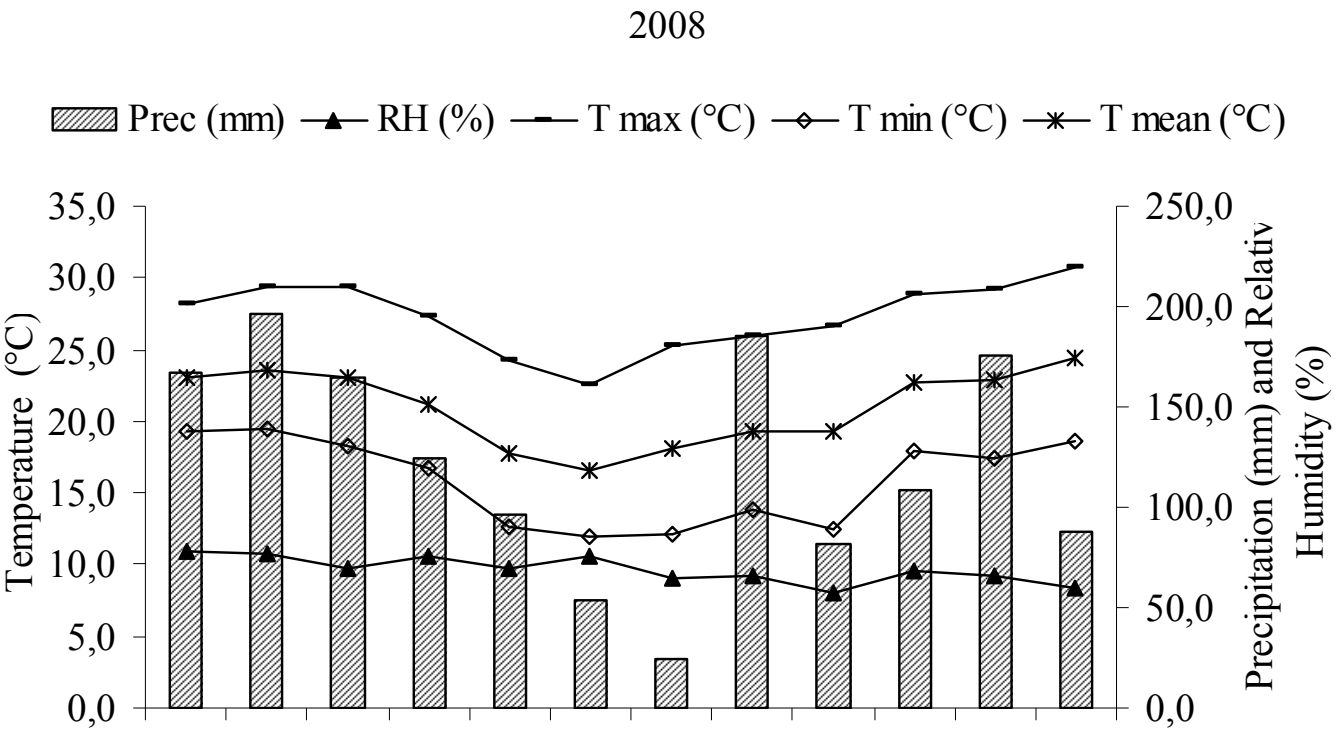

Jan Feb Mar Apr May Jun Jul Aug Sept Oct Nov Dec

Figure 5. Monthly temperature, relative humidity and precipitation from January to December of 2010. Londrina PR, Brazil.

2010

mIm Prec $(\mathrm{mm}) \quad \mathrm{T} \max \left({ }^{\circ} \mathrm{C}\right) \rightarrow \mathrm{T} \min \left({ }^{\circ} \mathrm{C}\right) \quad$ * $\mathrm{T}$ mean $\left({ }^{\circ} \mathrm{C}\right) \rightarrow \mathrm{RH}(\%)$

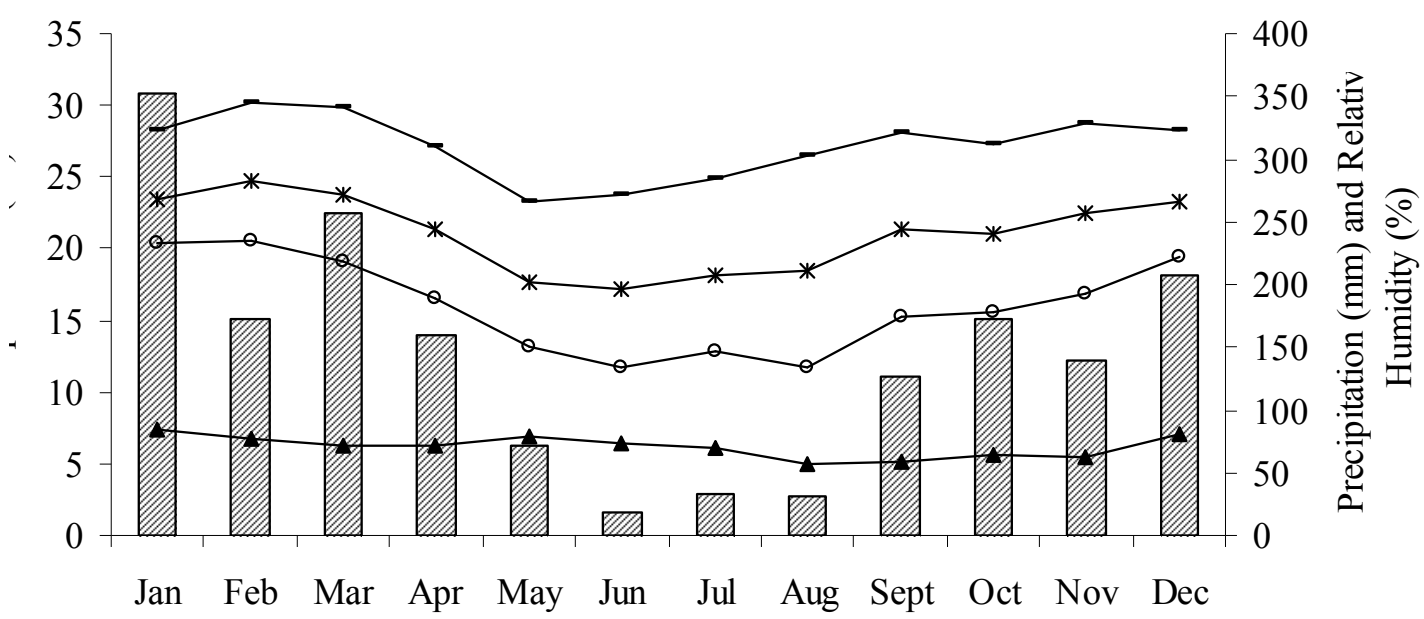




\section{Acknowledgements}

We acknowledge the State University of Londrina (Universidade Estadual de Londrina), the Brazilian Coffee Research and Development Consortium (Consórcio Brasileiro de Pesquisa e Desenvolvimento do Café - CBP\&D Café), and Embrapa Café for financial support and the granted scholarship.

\section{References}

BATCHVAROVA, R. B.; REDDY, V. S.; BENNETT, J. Cellular resistance in rice to cercosporin, a toxin of Cercospora. Phytopathology, Saint Paul, v. 82, n. 6, p. 642-646, 1992.

BLACK, C. R.; ONG, C. K. Utilization of light and water in tropical agriculture. Agriculture and Forest Meteorology, Amsterdam, v. 104, n. 1, p. 25-47, 2000.

BOTELHO, D. M. S.; POZZA, E. A.; ALVES, E.; BOTELHO, C. E.; POZZA, A. A. A.; RIBEIRO JÚNIOR, P. M.; SOUZA, P. E. Efeito do silício na intensidade da cercosporiose e na nutrição mineral de mudas de cafeeiro. Arquivos do Instituto Biológico, São Paulo, v. 78, n. 1, p. 23-29, 2011.

CANTERI, M. G.; ALTHAUS, R. A.; VIRGENS FILHO, J. S.; GIGLIOTI, E. A.; GODOY, C. V. SASM - Agri: Sistema para análise e separação de médias em experimentos agrícolas pelos métodos Scoft - Knott, Tukey e Duncan. Revista Brasileira de Agrocomputação, Ponta Grossa, v. 1, n. 2, p. 18-24, 2001.

CANTERI, M. G.; GODOY, C. V.; PONTE, E. M. del; FERNANDES, J. M. C.; PAVAN, W. Aplicações da computação na fitopatologia. Revisão Anual de Patologia de Plantas, Passo Fundo, v. 12, p. 243-285, 2004.

CARAMORI, P. H.; KATHOUNIAN, C. A.; MORAIS, H.; LEAL, A. C.; HUGO, R. G.; ANDROCIOLI, A. Arborização de cafezais e aspectos climatológicos. In: MATSUMOTO, S. N. (Ed.). Arborização de cafezais no Brasil. Vitória da Conquista: UESB Editions, 2004. Chapter 3, p. 19-42.

CUSTÓDIO, A. A. de P.; POZZA, E. A.; CUSTÓDIO, A. A. de P.; SOUZA, P. E. de; LIMA, L. A.; LIMA, L. M. de. Intensidade da ferrugem e da cercosporiose em cafeeiros quanto à face de exposição das plantas. Coffee Science, Lavras, v. 5, n. 3, p. 214-228, 2010.
DAUB, M. E.; HERRERO, S.; CHUNG, K. R. Photoactived perylenequinone toxins in fungal pathogenesis of plants. FEMS Microbiology, Lerrer, v. 252, n. 2, p. 197-206, 2005.

EMPRESA BRASILEIRA DE PESQUISA AGROPECUÁRIA - EMBRAPA. Centro Nacional de Pesquisa de Solos. Sistema Brasileiro de Classificação de Solos. Brasília: Serviço de Produção de Informação, 1999. $412 \mathrm{p}$.

GARCIA JÚNIOR, D.; POZZA, E. A; POZZA, A. A. A.; SOUZA, P. E.; CARVALHO, J. G.; BALIEIRO, A.C. Incidência e severidade da cercosporiose do cafeeiro em função do suprimento de potássio e cálcio em solução nutritive. Fitopatologia Brasileira, Brasília, v. 28, n. 3, p. 286-291, 2003.

GODOY, C. V.; BERGAMIN FILHO, A.; SALGADO, C. L. Doenças do cafeeiro (Coffea arábica L.). In: KIMATI, H. Manual de fitopatologia: doenças de plantas e seu controle. 3. ed. São Paulo: Agronômica Ceres, 1997. v. 2, p. 184-200.

GUHARAY, F.; MONTERROSO, D.; STAVER, C. El diseño y manejo de la sombra para la superasión de plagas en cafetales de América Central. Agroforesteria en las Américas, Turrialba, v. 8, n. 29, p. 22-27, 2001.

HAIRIAH, K.; SULISTYANI, H.; SUPRAYOGO, D.; PURNOMOSIDHI, W. P.; WIDODO, R. H.; NOORDWIJK, M. van. Litter layer residence time in forest and coffee agroforestry systems in Sumberjaya, West Lampung. Forest Ecology and Management, Amsterdam, v. 224, n. 1, p. 45-57, 2006.

INSTITUTO AGRONÔMICO DO PARANÁ - IAPAR. Cartas climáticas do Paraná. Lonrina: Iapar, 2010. Disponível em: <http://www.iapar.br>. Acesso em: 19 maio 2014.

JARAMILlO, R. A.; CHÁVES, C. B. Aspectos hidrológicos en un bosque y em plantaciones de café al sol y bajo sombra. Cenicafé, Manizales, v. 50, n. 2, p. 97-105, 1999.

LOPES, P. R.; ARAÚJO, K. C. S.; FERRAZ, J. M. G.; LOPES, I. M.; FERNANDES, L. G. Produção de café agroecológico no sul de Minas Gerais: sistemas alternativos à produção intensiva em agroquímicos. Revista Brasileira de Agroecologia, Cruz Alta, v. 7, n. 1, p. 25-38, 2012.

MARTINS, M.; MENDES, A. N. G.; ALVARENGA, M. I. N. Incidência de pragas e doenças em agroecossistemas de café orgânico de agricultores familiares em Poço Fundo, MG. Ciência e Agrotecnologia, Lavras, v. 28, n. 6, p. 1306-1313, nov./dez. 2004. 
MORAIS, H.; CARAMORI, P. H.; KOGUISHI, M. S.; RIBEIRO, A. M. A. de. Caracterização microclimática de cafeeiros cultivados sob malha de sombreamento e a pleno sol. Revista Brasileira de Agrometeorologia, Piracicaba, v. 15, n. 2, p. 133-142, fev. 2007.

NEVES, Y. P.; MARTINEZ, H. E. P.; SOUZA, C. M.; CECON, P. R. Teor de água e fertilidade do solo com cafeeiros cultivados em sistemas agroflorestais. Revista Árvore, Viçosa, v. 31, n. 4, p. 575-588, 2007.

PEZZOPANE, J. R. M.; PEDRO JÚNIOR, M. J.; GALLO, P. B. Caracterização microclimática em cultivo consorciado café/banana. Revista Brasileira de Engenharia Agrícola e Ambiental, Campina Grande, v. 11, n. 3, p. 256-264, 2007.

ROMERO-ALVARADO, Y.; PINTO, L. S.; BARRIOS, L. G.; BARRERA -GAYTÁN, J. F. Coffee yields and soil nutrients under the shades of Inga $s p$. Vs. Multiple species in Chiapas, Mexico. Agroforestry Systems, Holland, v. 54, n. 3, p. 215-224, 2002.

SALGADO, B. G.; MACEDO, R. L. G.; CARVALHO, V. L.; SALGADO, M.; VENTURINS, N. Progresso da ferrugem e da cercosporiose do cafeeiro consorciado com grevílea, com ingazeiro e a pleno sol em Lavras, MG. Ciência e Agrotecnologia, Lavras, v. 31, n. 3, p. 1067-1074, 2007.
SAMAYOA, J. O. J.; SANCHEZ, V. G. Enfermedades foliares en café orgánico y convencional. Manejo Integrado de plagas, Turrialba, v. 2, n. 58, p. 9-19, 2000.

SANTOS, F. S.; SOUZA, P. E.; POZZA, E. A.; MIRANDA, J. C.; CARVALHO, E. A.; FERNANDES, L. H. M.; POZZA, A. A. A. Adubação orgânica, nutrição e progresso de cercosporiose e ferrugem do cafeeiro. Pesquisa Agropecuária Brasileira, Brasília, v. 43, n. 7, p. 783-791, 2008.

TALAMINI, V.; SOUZA, P. E.; POZZA, E. A.; SILVA, A. M.; BUENO FILHO, J. S. S. Progresso da ferrugem e da cercosporiose do cafeeiro (Coffea arabica L.) em diferentes lâminas de irrigação e diferentes parcelamentos da adubação. Ciência e Agrotecnologia, Lavras, v. 25, n. 1, p. 55-62, 2001.

ZAMBOLIM, L.; VALE, F. X. R. do; PEREIRA, A. A.; CHAVES, G. M. Café (Coffea arabica L.) - controle de doenças. In: VALE, F. X. R. do; ZAMBOLIM, L. (Ed.). Controle de doenças de plantas: grandes culturas. Viçosa: UFV; Brasília: Ministério da Agricultura e Abastecimento, 1997. v. 2, p. 83-179. 